\title{
Enzymatic isomerization of glucose and xylose in ionic liquids
}

\section{Ståhlberg, Tim Johannes Bjarki; Woodley, John; Riisager, Anders}

\section{Published in:}

Catalysis Science \& Technology

Link to article, DOI:

$10.1039 /$ c1cy00155h

Publication date:

2012

Document Version

Publisher's PDF, also known as Version of record

Link back to DTU Orbit

Citation (APA):

Ståhlberg, T. J. B., Woodley, J., \& Riisager, A. (2012). Enzymatic isomerization of glucose and xylose in ionic liquids. Catalysis Science \& Technology, 2(2), 291-295. https://doi.org/10.1039/c1cy00155h

\section{General rights}

Copyright and moral rights for the publications made accessible in the public portal are retained by the authors and/or other copyright owners and it is a condition of accessing publications that users recognise and abide by the legal requirements associated with these rights.

- Users may download and print one copy of any publication from the public portal for the purpose of private study or research.

- You may not further distribute the material or use it for any profit-making activity or commercial gain

- You may freely distribute the URL identifying the publication in the public portal

If you believe that this document breaches copyright please contact us providing details, and we will remove access to the work immediately and investigate your claim. 


\section{Catalysis Science \& Technology

\section{Cite this: Catal. Sci. Technol., 2012, 2, 291-295

\section{Enzymatic isomerization of glucose and xylose in ionic liquids $\dagger$}

\begin{abstract}
Tim Ståhlberg, ${ }^{a}$ John M. Woodley ${ }^{b}$ and Anders Riisager*a
Received 5th May 2011, Accepted 9th November 2011 DOI: $10.1039 / \mathrm{c} 1 \mathrm{cy00155h}$

Glucose isomerase has been found for the first time to catalyze the isomerization of glucose to fructose in the ionic liquid $\mathrm{N}, \mathrm{N}$ dibutylethanolammonium octanoate (DBAO). Isomerization was achieved at temperatures of $60-80^{\circ} \mathrm{C}$ although a substantial amount of mannose was formed at elevated temperatures via the Lobry-de Bruyn-van Ekenstein transformation. Complete recovery of the sugars after reaction was achieved by extraction with aqueous $\mathrm{HCl}$, thus making the protocol attractive for continuous operation.
\end{abstract}

\section{Introduction}

The increased demand for sustainable and environmentally benign chemical processes makes enzymes attractive alternatives as catalysts in industrial processes. Enzymes are by virtue most effective in aqueous environments where many chemical substrates and products have low solubility. Therefore the search for alternative solvents in which enzymes have retained activity is of the essence.

Ionic liquids (ILs) are interesting alternatives to conventional organic solvents due to their negligible vapor pressure, nonflammability and unique dissolving abilities for polar compounds and polymers. ${ }^{1}$ The study of enzymes in ILs has intensified over recent years and many interesting examples are covered in two excellent reviews by Sheldon and coworkers. ${ }^{2,3}$ In particular lipases have proven to be stable and have retained or improved activity in ILs. ${ }^{4-15}$ Other noteworthy examples are the synthesis of aspartame with thermolysin in 1-butyl-3-methylimidazolium hexafluorophosphate $\left([\mathrm{BMIm}]\left[\mathrm{PF}_{6}\right]\right)^{16}$ and the oxidation of cellobiose with cytochrome $c$ in hydrated choline dihydrogen phosphate ([Choline][dhp]). ${ }^{17,18}$ An additional advantage with ILs in combination with enzymes is the possibility for two-phase systems with supercritical fluids. Combining IL/enzyme mixtures with supercritical $\mathrm{CO}_{2}$ enables a dynamic system where products or reactants can be selectively removed from the reaction mixture. ${ }^{4}$

Glucose isomerase (GI) catalyzes the isomerization of glucose to fructose and is used for the production of highfructose corn syrup (HFCS) which is currently one of the most

${ }^{a}$ Centre for Catalysis and Sustainable Chemistry, Department of Chemistry, Technical University of Denmark, DK-2800 Kgs. Lyngby, Denmark.E-mail: ar@kemi.dtu.dk

${ }^{b}$ Centre for Process Engineering and Technology, Department of Chemical and Biochemical Engineering, Technical University of Denmark, DK-2800 Kgs. Lyngby, Denmark

$\dagger$ Electronic supplementary information (ESI) available. See DOI: $10.1039 / \mathrm{c} 1 \mathrm{cy} 00155 \mathrm{~h}$

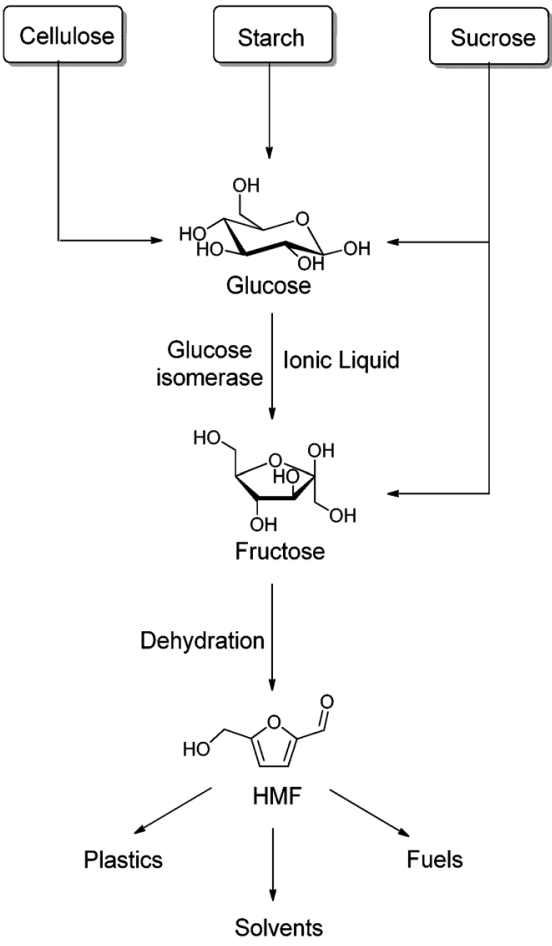

Scheme 1 Isomerization of glucose to fructose and its further derivatization to biopetrochemicals.

important industrial bioprocesses (Scheme 1). ${ }^{19}$ The process is limited by the poor yield of fructose and in spite of significant research on enriching fructose, the process currently requires an expensive chromatographic step to achieve the desired fructose concentration. ${ }^{19-21}$ The process usually works in water and examples in the literature of GI in alternative solvents are scarce, nevertheless successful isomerization has been achieved in aqueous ethanol, indicating that GI can maintain activity at reduced water concentrations. ${ }^{22}$ Finding an IL system where GI could exhibit activity would be of significant interest, not only for the food industry, but also since it potentially make one-pot reactions for future platform chemicals such as 5-hydroxymethyl furfural (HMF) possible. HMF is formed via the dehydration of hexoses and is readily obtained from fructose while the conversion from glucose requires special catalysts. ${ }^{23}$ HMF and its derivatives are believed to be among the most important platform chemicals of the future biopetrochemical industry. ${ }^{24}$ Given the high solubility of carbohydrates in ILs ${ }^{25}$ and the irreversible hydrolysis of HMF in aqueous solutions 
leading to levulinic acid and formic acid, a direct process from glucose to HMF in ILs has the potential to become an important industrial process in a post-petrochemical world. ${ }^{26,27}$

To the best of our knowledge, no successful enzymatic isomerization of glucose to fructose in ILs has been reported. We present here a study on GI in different ILs and show for the first time an IL/GI system that converts glucose to fructose enzymatically.

\section{Results and discussion}

\section{Screening of GI activity in various ILs}

GI is in industrial applications primarily used in its immobilized form. Sweetzyme ${ }^{\mathbb{R}}$ is a GI derived from a strain of the bacterium Streptomyces murinus and immobilized by the crosslinking of whole cells with glutaraldehyde. ${ }^{28}$ The activity of GI was first screened in several ILs using the immobilized GI Sweetzyme ${ }^{\circledR}$. Examples of anions and cations of the ILs screened are depicted in Scheme 2. Experiments without water and addition of 100 and $200 \mu \mathrm{L}$ of water were made. Since the ILs used had a different water content prior to the addition of water, the final water content varied in the final solution depending on the liquid. A complete list of the water content by weight before and after water addition is available as ESI $\dagger$ (Tables S1 and S2).

Most ILs had a detrimental effect on the enzyme activity whereas others simply did not dissolve glucose in reasonable amounts. In Table 1 the results of the ILs that gave conversion of glucose to fructose after 24 hours are shown. In all cases, the isomerization rate was significantly slower than in water, and the minor conversion to fructose observed with the basic acetate ILs was likely associated to direct base catalyzed isomerization rather than enzymatic activity. The two ILs most commonly employed for biomass conversion, 1-ethyl-3methylimidazolium chloride ([EMIm]Cl) and 1-butyl-3-methylimidazolium chloride $([\mathrm{BMIm}] \mathrm{Cl})$ both had a detrimental effect on enzyme activity and afforded no fructose. Most promising results were found using ammonium carboxylates, where $0.8 \mathrm{~mL} N, N$-dibutylethanolammonium octanoate (DBAO) together with $200 \mu \mathrm{L} \mathrm{H} \mathrm{H}_{2} \mathrm{O}$ gave a fructose yield of $52 \%$ after 24 hours. The addition of $200 \mu \mathrm{L} \mathrm{H}_{2} \mathrm{O}$ to DBAO corresponded

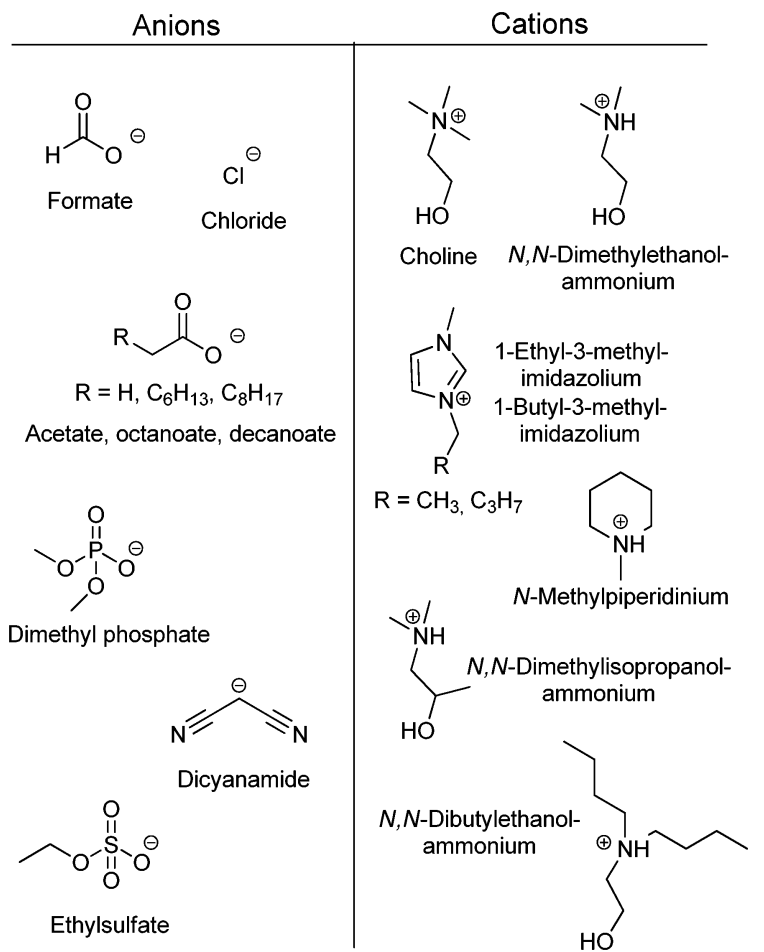

Scheme 2 Examples of different ions of the ionic liquids used in the initial screening.

to a final water content of $21 \mathrm{wt} \%$. In addition to fructose, $2 \%$ mannose was formed, most likely from fructose via the Lobry-de Bruyn-van Ekenstein transformation. ${ }^{29}$ Notably, no mannose was formed using any of the other ILs.

\section{Glucose isomerization in DBAO}

In Fig. 1 the results from the isomerization of glucose in DBAO over time are shown. After 1 hour around $25 \%$ fructose had formed, which was significantly slower than in water where equilibrium was reached already after 0.5 hours using the same batch of Sweetzyme ${ }^{R}$. After 4 hours in DBAO a glucose to fructose molar ratio of $49: 51$ was reached after which the fructose amount was stabilized at $52 \%$ while the mannose part increased at the expense of glucose over time. The $\mathrm{pH}$ of the $\mathrm{IL} / \mathrm{H}_{2} \mathrm{O}$-solution was neutral, suggesting that

Table 1 Isomerization of glucose to fructose in ILs with Sweetzyme ${ }^{\circledR}$ at equilibrium ${ }^{a}$

Glucose : fructose ratio $(\mathrm{mol}: \mathrm{mol})$

\begin{tabular}{|c|c|c|c|}
\hline Ionic liquid & $\mathrm{No}_{2} \mathrm{O}$ & $100 \mu \mathrm{L} \mathrm{H}{ }_{2} \mathrm{O}$ & $200 \mu \mathrm{L} \mathrm{H}_{2} \mathrm{O}$ \\
\hline$N, N$-Dimethylethanolammonium formate & $\mathrm{N} / \mathrm{A}$ & $95: 5$ & $94: 6$ \\
\hline$N, N$-Dimethylethanolammonium propionate & $\mathrm{N} / \mathrm{A}$ & $77: 23$ & $83: 17$ \\
\hline$N, N$-Dimethylethanolammonium decanoate & $\mathrm{N} / \mathrm{A}$ & $82: 18$ & $86: 14$ \\
\hline Choline propionate & $\mathrm{N} / \mathrm{A}$ & $96: 4$ & $95: 5$ \\
\hline$N, N$-Dimethylbutylammonium propionate & $\mathrm{N} / \mathrm{A}$ & $\mathrm{N} / \mathrm{A}$ & $87: 13$ \\
\hline$N$-Methylpiperidinium acetate & $\mathrm{N} / \mathrm{A}$ & $99: 1$ & $91: 9$ \\
\hline DBAO & $\mathrm{N} / \mathrm{A}$ & N/A & $46: 52^{b}$ \\
\hline $\mathrm{N}, \mathrm{N}$-Dimethylisopropanolammonium propionate & $80: 20$ & $82: 18$ & $89: 11$ \\
\hline$[$ Choline $][\mathrm{OAc}]$ & $94: 6$ & $95: 5$ & $94: 6$ \\
\hline [EMIm][OAc] & $95: 5$ & $95: 5$ & $95: 5$ \\
\hline [BMIm][OAc] & $94: 6$ & $94: 6$ & $93: 7$ \\
\hline
\end{tabular}




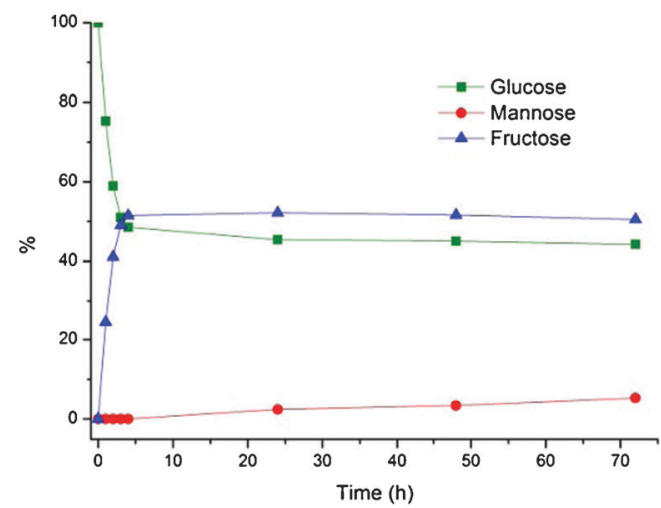

Fig. 1 Enzymatic conversion of glucose to fructose in DBAO at $60{ }^{\circ} \mathrm{C}$. Reaction conditions: $100 \mathrm{mg}$ glucose, $0.8 \mathrm{~g}$ DBAO, $0.2 \mathrm{~mL}$ $\mathrm{H}_{2} \mathrm{O}, 30 \mathrm{mg}$ Sweetzyme ${ }^{\circledR}$ and $3.3 \mathrm{mg} \mathrm{MgSO}_{4} \cdot 7 \mathrm{H}_{2} \mathrm{O}$.

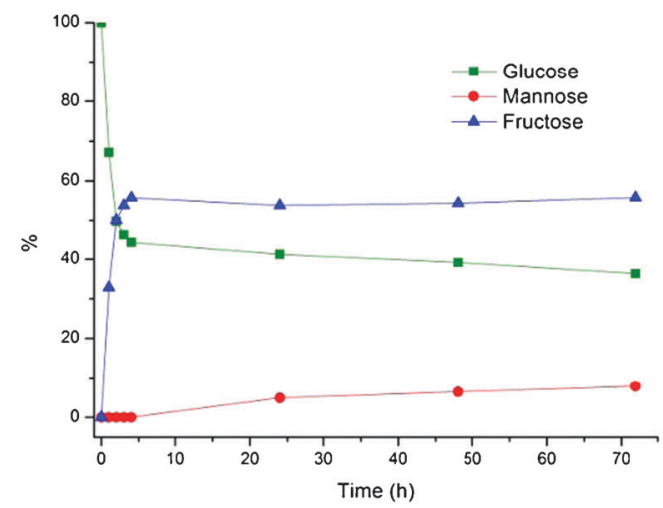

Fig. 2 Enzymatic conversion of glucose to fructose in DBAO at $70{ }^{\circ} \mathrm{C}$. Reaction conditions: $100 \mathrm{mg}$ glucose, $0.8 \mathrm{~g}$ DBAO, $0.2 \mathrm{~mL}$ $\mathrm{H}_{2} \mathrm{O}, 30 \mathrm{mg}$ Sweetzyme ${ }^{\circledR}$ and $3.3 \mathrm{mg} \mathrm{MgSO}_{4} \cdot 7 \mathrm{H}_{2} \mathrm{O}$.

the isomerization of fructose to mannose was a result of a specific base-catalysis.

Increasing the temperature to 70 and $80{ }^{\circ} \mathrm{C}$ retained enzyme activity in DBAO and equilibrium was reached both faster and with a greater enrichment of fructose, as expected at elevated temperatures (Fig. 2 and 3). ${ }^{19}$ At $70{ }^{\circ} \mathrm{C}$ a fructose content of $55 \%$ was reached after 4 hours and correspondingly an amount of $58 \%$ at $80{ }^{\circ} \mathrm{C}$. The amount of mannose was also increased and after 24 hours at $80{ }^{\circ} \mathrm{C}$ as much as $11 \%$ was

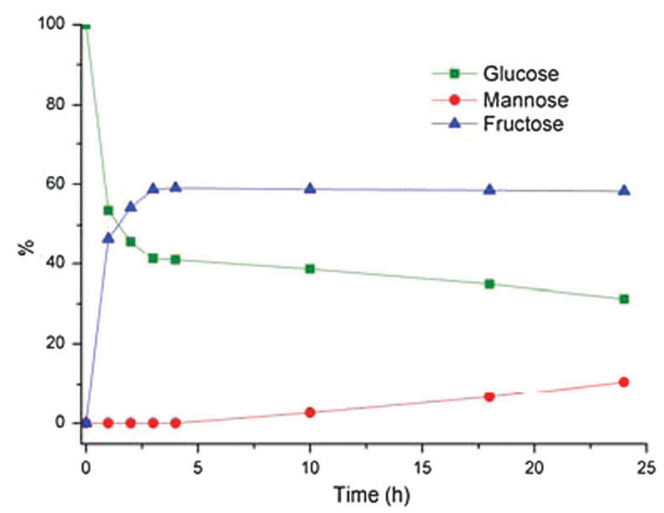

Fig. 3 Enzymatic conversion of glucose to fructose in DBAO at $80{ }^{\circ} \mathrm{C}$. Reaction conditions: $100 \mathrm{mg}$ glucose, $0.8 \mathrm{~g}$ DBAO, $0.2 \mathrm{~mL}$ $\mathrm{H}_{2} \mathrm{O}, 30 \mathrm{mg}$ Sweetzyme ${ }^{\circledR}$ and $3.3 \mathrm{mg} \mathrm{MgSO}_{4} \cdot 7 \mathrm{H}_{2} \mathrm{O}$.
Table 2 Initial rate constants for glucose isomerization

\begin{tabular}{lll}
\hline Temperature $/{ }^{\circ} \mathrm{C}$ & Rate const. DBAO $/ \mathrm{h}^{-1}$ & Rate const. $\mathrm{H}_{2} \mathrm{O} / \mathrm{h}^{-1}$ \\
\hline 60 & 0.27 & 0.71 \\
70 & 0.35 & 1.14 \\
80 & 0.80 & 1.46 \\
\hline
\end{tabular}

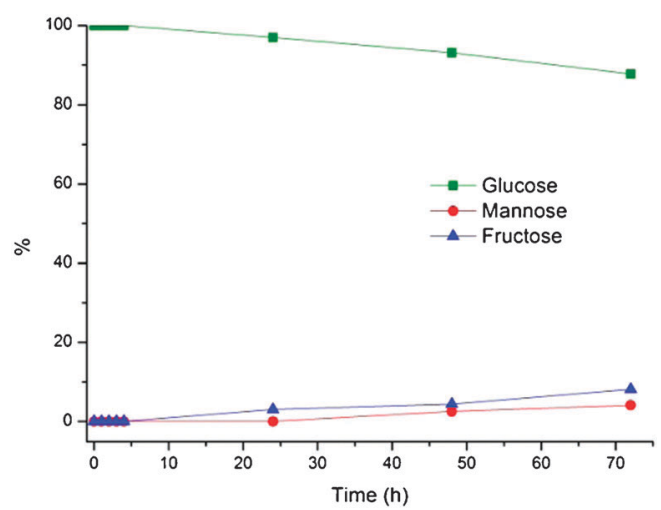

Fig. 4 Conversion of glucose to fructose in DBAO at $60{ }^{\circ} \mathrm{C}$ without enzyme. Reaction conditions: $100 \mathrm{mg}$ glucose, $0.8 \mathrm{~g}$ DBAO, $0.2 \mathrm{~mL}$ $\mathrm{H}_{2} \mathrm{O}$, and $3.3 \mathrm{mg} \mathrm{MgSO}_{4} \cdot 7 \mathrm{H}_{2} \mathrm{O}$.

reached whereas glucose only amounted to $31 \%$. No mannose was formed after 4 hours in either case which indicated that a certain amount of fructose was formed before the chemical isomerization of fructose to mannose was initiated. However, by-product formation was a problem over longer reaction times and after 48 hours significant caramelization of the sugars had taken place. The initial rate constants for the isomerization at all three temperatures in DBAO as well as the corresponding rates in water are listed in Table 2. The reaction was considered to be first order with respect to glucose concentration.

Work-up after complete isomerization was done by extracting the IL with $1 \mathrm{M} \mathrm{HCl}$. A single extraction with an equal volume of acid solution to IL resulted in complete recovery of the sugars to the aqueous phase. Water and DBAO formed a homogeneous clear solution when using $200 \mu \mathrm{L}$ of water and $0.0135 \mathrm{mmol}$ of $\mathrm{MgSO}_{4}$ at temperatures of $60{ }^{\circ} \mathrm{C}$ and above, but formed a clear two phase system with $1 \mathrm{M} \mathrm{HCl}$. This provides a separation method that can be suitable for large scale production of these sugar mixtures.

In order to verify that the observed glucose isomerization in DBAO was enzymatically catalyzed, glucose was left to stir under normal reaction conditions without the addition of Sweetzyme $^{\circledR}$. This resulted in $8 \%$ fructose after 72 hours, confirming that the high fructose yields in the former experiments were a result of catalysis by the active enzyme (Fig. 4).

\section{Xylose isomerization in DBAO}

The natural substrate of GI is xylose which is isomerized catalytically in nature to xylulose. The isomerization of xylose to xylulose exhibits a different product distribution upon reaching equilibrium than that of glucose to fructose. The thermodynamic equilibrium between the two pentoses is $86: 14$, respectively. ${ }^{30-32}$ 


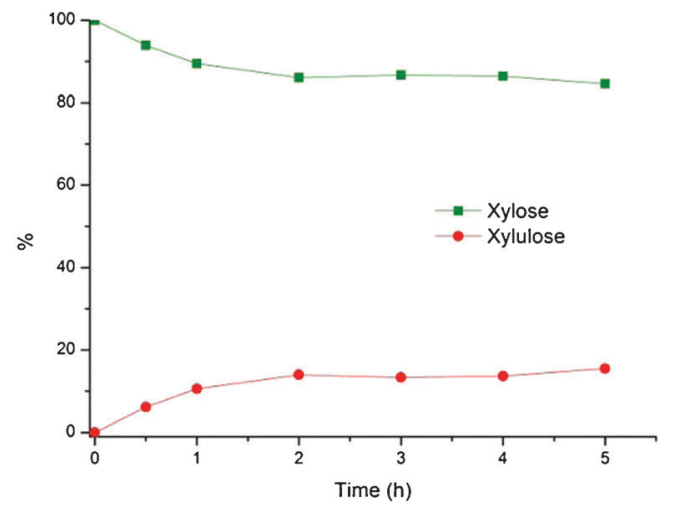

Fig. 5 Enzymatic conversion of xylose to xylulose in DBAO at $60{ }^{\circ} \mathrm{C}$. Reaction conditions: $100 \mathrm{mg}$ xylose, $0.8 \mathrm{~g}$ DBAO, $0.2 \mathrm{~mL} \mathrm{H}_{2} \mathrm{O}, 30 \mathrm{mg}$ Sweetzyme ${ }^{\circledR}$ and $3.3 \mathrm{mg} \mathrm{MgSO}_{4} \cdot 7 \mathrm{H}_{2} \mathrm{O}$.

When using the DBAO system equilibrium was reached already after two hours as would be expected since it is the natural substrate of the enzyme (Fig. 5). ${ }^{19}$ After 24 hours significant degradation had occurred indicated by an increase of several unidentified peaks during HPLC analysis, suggesting that the xylose and xylulose were less stable in the IL system compared to the hexoses.

\section{Experimental}

\section{Materials}

All chemicals were used as received. D-glucose $(99.5 \%)$ and xylose $(99 \%)$ were purchased from Aldrich. D-fructose (puriss) was purchased from Riedel-de Haën. [EMIm]Cl and [BMIm] Cl were obtained from BASF while all other ILs were purchased from CLEA Technologies. Sweetzyme ${ }^{\mathbb{R}}$ was obtained from Novozymes A/S.

All experiments were performed using a Radley Carousel 12 Plus Basic System with temperature control $\left( \pm 1^{\circ} \mathrm{C}\right)$. Samples were analyzed by HPLC (Agilent 1200 series, Phenomenex Rezex RCM-Monosaccharide $\mathrm{Ca}^{2+}(\%), 300 \times 7.8 \mathrm{~mm}$ pre-packed column, MilliQ water as mobile phase, $80{ }^{\circ} \mathrm{C}$, $0.6 \mathrm{~mL} \mathrm{~min}{ }^{-1}$ ). Peaks were identified from standards of all products and substrates.

\section{General procedure for isomerization}

Ionic liquid (0.8-1.0 g), $\mathrm{MgSO}_{4} \cdot 7 \mathrm{H}_{2} \mathrm{O}(3.3 \mathrm{mg}, 0.0135 \mathrm{mmol})$, water $(0-0.2 \mathrm{~mL})$ and sugar $(100 \mathrm{mg}, 9 \mathrm{wt} \%)$ were stirred for 5 minutes and a clear homogeneous solution was obtained. Sweetzyme ${ }^{\circledR}(30 \mathrm{mg})$ was added and the reaction was allowed to stir for a maximum of 72 hours. Samples were taken out during the reaction and analyzed by HPLC.

\section{Conclusions}

The first successful enzymatic conversion of glucose to fructose as well as xylose to xylulose in ILs is reported. During isomerization of glucose the formed fructose was converted to mannose via the Lobry-de Bruyn-van Ekenstein transformation leading to an accumulation of fructose and mannose at the expense of glucose over time. The activity of the enzyme was lower in ILs in comparison to water resulting in slower reaction rates.
Xylose isomerization was, however, faster in comparison to glucose as would be expected being the natural substrate of the enzyme. It is reasonable to believe that the surface of the enzyme is hydrated and hence facilitates activity even in the presence of the IL. Analogous to the previous report on ethanol $^{22} 21 \mathrm{wt}^{2} \%$ of water was used for the reactions. In this study, however, solubility of the sugar and $\mathrm{MgSO}_{4}$ - not enzyme activity — was the main reason for using this particular solvent composition.

The conversion of biomass to commodity chemicals is alongside the production of sweeteners the most important future application of this catalytic system. Hence, our work will continue with studies of fructose dehydration to $\mathrm{HMF}$ using Lewis and Brønsted acid catalysts like, e.g. $\mathrm{WCl}_{6}{ }^{33}$ $\mathrm{CrCl}_{3},{ }^{34,35}$ or $\mathrm{HCl}^{36}$ in DBAO at elevated temperatures.

We believe that this work provides interesting discoveries concerning the compatibility of GI and ILs and could initiate further studies on GI in alternative solvents. Furthermore, it facilitates opportunities to make a one-pot synthesis of platform chemicals from glucose or its natural polymers.

\section{Acknowledgements}

The reported work was supported by the Danish National Advanced Technology Foundation in cooperation with Novozymes A/S. Special gratitude to BASF for providing the ionic liquids.

\section{Notes and references}

$1 \mathrm{P}$. Wasserscheid and T. Welton, Ionic Liquids in Synthesis, Wiley-VCH Verlag GmbH \& Co. KGaA, 2008.

2 R. A. Sheldon, R. M. Lau, M. J. Sorgedrager, F. van Rantwijk and K. R. Seddon, Green Chem., 2002, 4, 147-151.

3 F. van Rantwijk and R. A. Sheldon, Chem. Rev., 2007, 107, $2757-2785$.

4 R. Bogel-Łukasik, V. Najdanovic-Visak, S. Barreiros and M. Nunes da Ponte, Ind. Eng. Chem. Res., 2008, 47, 4473-4480.

5 R. M. Lau, F. van Rantwijk, K. R. Seddon and R. A. Sheldon, Org. Lett., 2000, 2, 4189-4191.

6 M. Eckstein, P. Wasserscheid and U. Kragl, Biotechnol. Lett., 2002, 24, 763-767.

7 P. Lozano, T. de Diego, D. Carrie, M. Vaultier and J. L. Iborra, Chem. Commun., 2002, 692-693.

8 M. T. Reetz, W. Wiesenhofer, G. Francio and W. Leitner, Chem. Commun., 2002, 992-993.

9 R. M. Lau, M. J. Sorgedrager, G. Carrea, F. van Rantwijk, F. Secundo and R. A. Sheldon, Green Chem., 2004, 6, 483-487.

10 T. De Diego, P. Lozano, S. Gmouh, M. Vaultier and J. L. Iborra, Biomacromolecules, 2005, 6, 1457-1464.

11 F. van Rantwijk, F. Secundo and R. A. Sheldon, Green Chem., 2006, 8, 282-286.

12 H. Shan, Z. Li, M. Li, G. Ren and Y. Fang, J. Chem. Technol. Biotechnol., 2008, 83, 886-891.

13 R. Bogel-Łukasik, N. M. T. Lourenço, P. Vidinha, M. D. R. Gomes da Silva, C. A. M. Afonso, M. Nunes da Ponte and S. Barreiros, Green Chem., 2008, 10, 243-248.

14 Z. Guo and X. Xu, Org. Biomol. Chem., 2005, 3, 2615-2619.

15 M. Adamczak and U. T. Bornscheuer, Process Biochem., 2009, 44, 257-261.

16 M. Erbeldinger, A. J. Mesiano and A. J. Russell, Biotechnol. Prog., 2000, 16, 1129-1131.

17 K. Fujita, D. R. MacFarlane, M. Forsyth, M. Yoshizawa-Fujita, K. Murata, N. Nakamura and H. Ohno, Biomacromolecules, 2007, 8, 2080-2086.

18 K. Fujita, N. Nakamura, K. Igarashi, M. Samejima and H. Ohno, Green Chem., 2009, 11, 351-354. 
19 S. Bhosale, M. Rao and V. Deshpande, Microbiol. Rev., 1996, 60, $280-300$.

20 S. A. Barker, H. Pelmore and P. J. Somers, Enzyme Microb. Technol., 1983, 5, 121-124.

21 Y. Takasaki, Agric. Biol. Chem., 1971, 35, 1371-1375.

22 K. Visuri and A. M. Klibanov, Biotechnol. Bioeng., 1987, 30, 917-920.

23 J. Lewkowski, ARKIVOC, 2001, 17, 54.

24 J. J. Bozell and G. R. Petersen, Green Chem., 2010, 12, $539-554$.

25 M. E. Zakrzewska, E. Bogel-Łukasik and R. Bogel-Łukasik, Energy Fuels, 2010, 24, 737-745.

26 T. Ståhlberg, W. Fu, J. M. Woodley and A. Riisager, ChemSusChem, 2011, 4, 451-458.

27 M. E. Zakrzewska, E. Bogel-Łukasik and R. Bogel-Łukasik, Chem. Rev., 2011, 111, 397-417.
28 O. B. Jörgensen, L. G. Karlsen, N. B. Nielsen, S. Pedersen and S. Rugh, Starch/Staerke, 1988, 40, 307-313.

29 C. A. Lobry de Bruyn and W. Alberda van Ekenstein, Recl. Trav. Chim. Pays-Bas, 1897, 16, 274-281.

30 R. M. Hochster and R. W. Watson, Arch. Biochem. Biophys., 1954, 48, 120-129.

31 K. J. Schray and I. A. Rose, Biochemistry, 1971, 10, 1058-1062.

32 M. Whitlow, A. J. Howard, B. C. Finzel, T. L. Poulos, E. Winborne and G. L. Gilliland, Proteins: Struct., Funct., Genet., 1991, 9, 153-173.

33 J. Y. G. Chan and Y. Zhang, ChemSusChem, 2009, 2, 731-734.

34 H. Zhao, J. E. Holladay, H. Brown and Z. C. Zhang, Science, 2007, 316, 1597-1600.

35 G. Yong, Y. Zhang and J. Ying, Angew. Chem., Int. Ed., 2008, 47, 9345-9348.

36 L. Lai and Y. Zhang, ChemSusChem, 2010, 3, 1257-1259. 